\title{
EMBRYONIC DEVELOPMENT AND BEHAVIOUR OF JAPANESE QUAIL EXPOSED TO MICROGRAVITY
}

\author{
K. BOĎA ${ }^{1}$, V. SABO ${ }^{1}$, M. JURÁNI ${ }^{1}$, T. S. GURYEVA ${ }^{2}$, J. KOČIŠOVÁ ${ }^{3}$, L. KOŠŤÁL ${ }^{1}$, \\ A. LAUKOVÁ ${ }^{3}$ and O. A. DADASHEVA \\ Institute of Animal Biochemistry and Genetics SAS, 90028 Ivanka pri Dunaji ${ }^{1}$, Institute of \\ Biomedical Problems, Moscow ${ }^{2}$, and Institute of Animal Physiology SAS, 04801 Košice $^{3}$
}

Received November 20, 1991

\begin{abstract}
Bođa K., V. Sabo, M. Juráni, T. S. Guryeva, J. Kočišová, L. Koštál, A. Lauková, O. A. Dadasheva: Embryonic Development and Behaviour of fapanese Quail Exposed to Microgravity. Acta vet. Brno, 61, 1992: 99-107.

The effect of microgravity on the embryonic development of Japanese quail including hatching, the behaviour of newly hatched chickens and physiological functions of adult birds were studied. The feasibility of the entire embryonic development as well as hatching of quail in weightlessness was demonstrated. Priority data on sensory, motor and feeding behaviour of 1- to 4-day-old quail hatchlings as well as the behaviour of adult birds in microgravity were obtained. Under special conditions the quail were able to take food, but were generally unable to adapt their motor activity to microgravity at any time during the experiment. Their movements were uncoordinated and chaotic, particularly so in chicks. After a 7-day exposure to microgravity hormone levels (estradiol, triiodthyronine, corticosterone) and $\mathrm{Ca}$ in mature quail were determined. Changes in reproductive functions were manifested by the arrest of egg production, dystrophy of ovaries and testes and a decreased testosterone level. The first data on the effects of microgravity on the enteric microflora were also obtained.
\end{abstract}

fapanese quail, microgravity, embryogenesis, behaviour, hormones, enteric microbiology

The establishment of biological systems utilizing animals to suppot the life of cosmonauts during long-term missions in orbital and planetary stations has become an object of the general study of cosmic biology (Shepelev 1975).

The animals selected should have a higher heterotrophic link in the self-sustaining ecosystem and will be required to live and produce under conditions of microgravity. The first experimental goal to meet these criteria is to study the potencial for the avian model. Due to its relatively low body mass and high performance converting feed to meat, the Japanese quail has been used (Boda 1979).

Since 1973 a series of experiments was conducted in which biological as well as technological problems, aimed at the realization of flight experiments, were undertaken. These experiments included adaptation mechanisms of quail to changed gravity (Juráni et al. 1980) problems connected with overcoming stress caused by the transport to orbit (Peter et al. 1978), the effect of long-term hypodynamy on the performance and breeding of a line of quail resistant to hypodynamy (Juráni et al. 1988).

Technological preconditions to study the entire reproductive cycle of the birds under the microgravity of Earth-orbital flight were provided by the construction and production of the devices İncubator 1 (Šutek et al. 1984; Souček et al. 1984), Incubator $1 M$ and NEST (Máiek and Zongor 1991).

Results obtained in these experiments have become the starting point to study avian microgravity under real space flight conditions.

Experiments were designed to determine the effect of microgravity on the embryonic development of Japanese quail including hatching, behaviour of hatchlings during the first post-hatching days, and behaviour, hormone levels and enteric microbiology in adult birds. 


\section{Materials and Metods}

The first experiment Incubator 1 was conducted in the automated biological satellite, Cosmos 1129 , in October 1979. It provided for a 12-day experiment. In each of three groups (flight experiment, synchronous and laboratory controls) 60 eggs were used. Eggs were obtained from the Institute of Biomedical Problems in Moscow. They were collected within 3 days and kept at $10^{\circ} \mathrm{C}$ before the experiment was started. In the flight experiment, the eggs placed into the incubator ( $3 \mathrm{~d}$ prior to start) were kept at $19^{\circ} \mathrm{C}$. Their age on the day of spaceship launching was $3-5 \mathrm{~d}$. After the start the eggs were kept at $23-25^{\circ} \mathrm{C}$ until the incubator was put to operation (i. e. 10 th day of flight). The synchronous and laboratory control eggs were stored for 10 days at $10^{\circ} \mathrm{C}$ before their incubation was started. In the flight and synchronous control the eggs were placed in the device Incubator 1 while the control in a laboratory incubator.

After the landing of the satellite, that due to the breakdown of the parachute, had to endure a $160 \mathrm{G}$ shock, the embryonic material was immediately taken from 40 broken and 2 intact eggs. The remaining 18 intact eggs were placed in a transport incubator and delivered to the Laboratory in Moscow. Due to embryo mortality, incubation failed to continue after the landing of the satellite. Histological examinations of embryonic tissues were performer.

The second experiment Incubator 2A was carried out in 1990 (March 4 to 24, i. e. 21 days), on the orbital station MIR in the module Quant 2. Forty-three eggs were used in the flight experiment as well as in a synchronous control. These eggs originated from the 12th generation of a selected line of Japanese quail resistant to hypodynamy, bred at the Institute of Animal Biochemistry and Genetics, Slovak Academy of Sciences, Ivanka pri Dunaji. After a 12-day storage time at $9.5^{\circ} \mathrm{C}$, the eggs for the flight experiment were transported to the orbital station in a special container (Fig. 1). The synchronous control experiment was carried out only after the flight experiment and the conditions in the maquette of the orbital station were similar to those in the orbital station MIR. Simultaneously, the laboratory control trial was carried out using a standard incubator.

To study the sequential dynamics of embryogenesis 8 eggs were fixed, 2 from each stage at day $4,8,12$, and 16 of embryogenesis. Thirty-five eggs were incubated for the entire 17-day period of embryogenesis. After hatching, the quail were placed in the NEST (Boda et al. 1991) where their behaviour was studied in the following 4 days. The birds were then fixed in $96 \%$ alcohol for morphological examinations.

The third experiment Incubator 2B was conducted from August 1 to 9, 1990 on the orbital station MIR using adult quail. In each of the three respective groups 4 quail were used ( 3 females and 1 male). The spaceship was launched on August 1, 1990 and on August 3 it joined the orbital complex MIR. The quail were transferred to the station MIR in transport containers on the same day and placed in the module Quant 2 in the NEST device.

Knowing of the inability of hatched quail to orientate in the microgravity environment in Experiment 2, a special harness was developed and used with the adults. They were harnessed and attached near the feeding tube. The general behaviour of harnessed as well as of non-harnessed birds in three experimental groups including feeding and mating behaviour were investigated.

On August 8, 1990 the quail were transferred back to the transport container and on August 9 they were returned to Earth. Ethological exau!usation were conducted and then 3 quail 


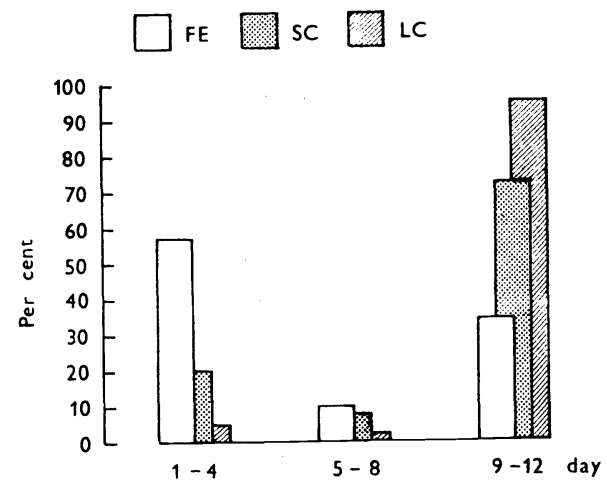

Fig. 2. Embryo development and mortality until day 12 of incubation. FE - flight experiment, SC - synchronous control, LC laboratory control

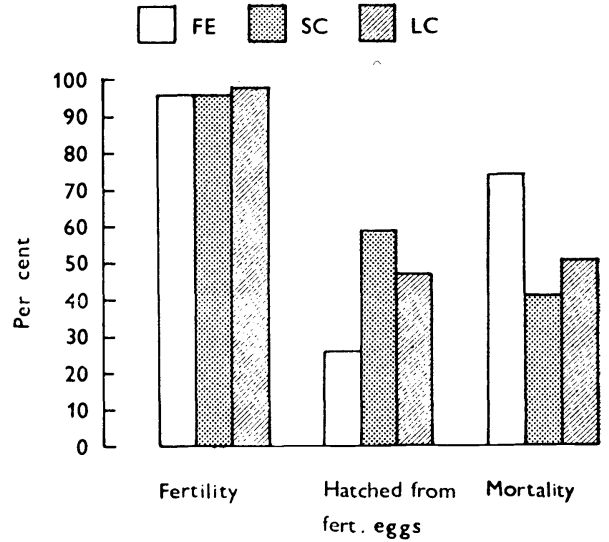

Fig. 3. Fertilization, hatching and mortality rates in single experiments. For explanation see Fig. 2.

( 2 females and 1 male) were killed by decapitation, 1 female immediately after landing, and another female and male the following day in the laboratory in Moscow. Blood was collected to examine plasma $\mathrm{Ca}$, corticosterone, testosterone, estradiol and triiodthyronine (Juráni et al. 1980, 1983). For histologic and electromicroscopic studies, samples from muscles (m. gastrocnemius) and testes were taken. Histochemically the activities of alkaline and acid phosphatases and non-specific esterase were studied. The enteric microflora was investigated in crop and caeca samples collected from 2 birds of each group. The samples were immersed in glycerol-phosphate buffer $(1: 1)$ and stored in dry ice.

\section{Results and Discussion}

Experiment Incubator 1 - 12-day Embryonic Development of Japanese Quail Under Microgravity Conditions

Results of the Incubator 1 experiment are presented in Fig. 2. The data indicate that embryogenesis was supported in the incubator: the flight experiment $33 \%$, the synchronous control $71.9 \%$, and the laboratory control $92.8 \%$, the embryos reaching the developmental stage of 9 to 12 days.

Mortality was highest in incuibator days $1-4$, especially in the flight experiment where it was $56.4 \%$ (synchronous control $19,3 \%$, laboratory control $4.8 \%$ ). At the developmental stage of 5-8 days, mortality was $10.3 \%$ in the flight experiment, $8.8 \%$ in the synchronous control and $2.4 \%$ in the laboratory control (Sabo et al. 1982).

Histologic investigation revealed no differences in tissues of 12-day-old embryos of the three groups (Bod'a et al. 1984, Maretta et al. 1984).

Quantitative differences in the number of developed embryos, especially between the flight experiment and synchronous control might have been caused by conditions of temperature and humidity in these groups during egg storage and also during the experiment. In the flight experiment the relative humidity varied. After 6 days of incubation humidity decreased due to a break-down of the humidity regulation system; it fell from $54-62 \%$ to $30 \%$ and remained at this level till the end of the experiment. 
The high mortality rate of embryos on day 1 to 4 of incubation in the flight experiment may have been caused by other yet unknown factors affecting early stages of embryogenesis under microgravity conditions. This is indirectly confirmed also by the results obtained from the experiment "Chix-in-Space" conducted on the American Space Shuttle Discovery. Of 16 eggs incubated 2 days on Earth, then exposed to a 5-day weightlessness and, after the landing, half opened for examination and half further incubated to hatch date, not even one embryo survived to embryonic stage day 7. From those 16 eggs incubated till 9 days on Earth prior to space flight a $100 \%$ viability was achieved (Hullinger et al. 1990).

Experiment Incubator 2A - Embryogenesis of Japanese Quail Under - Microgravity Conditions

The knowledge obtained from the experiment on the automated biological satellite Cosmos 1129 has broad implications for studying the entire embryonic development and hatching process as well as the first days of posthatching life.

Fig. 3 demonstrates the percentage of fertilization rate and hatchability of fertilized eggs and embryo mortality in both flight experiment and control groups. Though fertilization percentage was the same in all groups the flight experiment revealed the lowest hatchability and highest mortability. No significant changes were found between the synchronous and laboratory controls. Also in this experiment quantitative differences in the embryonic development were evidenced in flight and control groups indicating that further experiments are needed to focus attention to this problem. The results presented confirm our preliminary statistical data in the earlier studies obtained shortly before the final evaluation of ovoscopic control of the incubated eggs (Bod'a et al. 1991).

In this experiment it was also possible for the first time to study the behaviour of newly hatched quail in weightlessness and obtain fundamental data of the animal behaviour exposed for a longer time to microgravity.

The hatched quail had all the external characteristics of a normal development, they responded to visual and auditory stimuli, and manifested motor and vocal activity. They were not able to orient to the feeding tube and they lacked the ability of orientation and motor coordination in microgravity. They were bouncing against the walls of the NEST, and their wing and leg movements caused rotation along their own axis. They had to be hand-fed a food paste by the cosmonaut immediately after hatching and thereafter (Meleško et al. 1991; Bod'a et al. 1991).

As it was not possible to stabilize the quail in the NEST and feeding was solely dependent on help from the cosmonaut, the chicks were decapitated and placed into the fixative solution to later study their morphology.

Results obtained from the examination of hatched quail raise new questions and problems for cosmic biology. These center upon the apparent inability of the organism developing in microgravity to adapt itself to these conditions as far as sensory and motor coordination is concerned. Fundamentally the problem is how to manage the postembryonic development of hatchlings, apparently the keystone for completing the reproductive cycle of Japanese quail in microgravity conditions. 


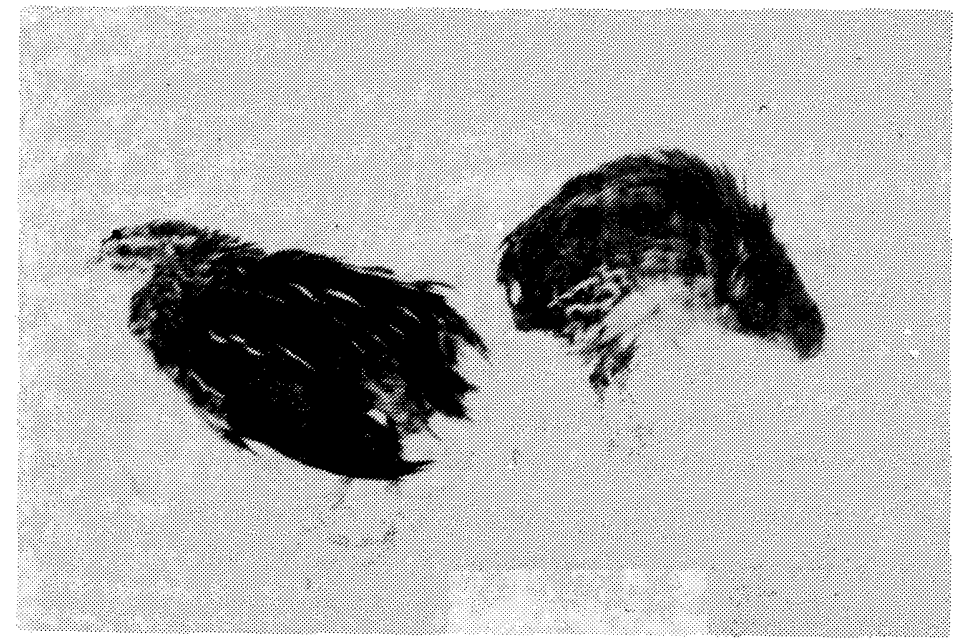

Fig. 4. Japanese quail after landing on Earth

Experiment Incubator 2B - Effect of a 7-day Microgravity on Physiological Functions of Adult Japanese Quail

After the successful experiment with embryogenesis and hatching process of quail in microgravity and the initial knowledge obtained on the behaviour of hatchlings, an experiment with adult quail was designed. The object of the study was the sensory and motor behaviour of adult birds, that in contrast to the newly hatched ones, have had previous experience in the gravitational field.

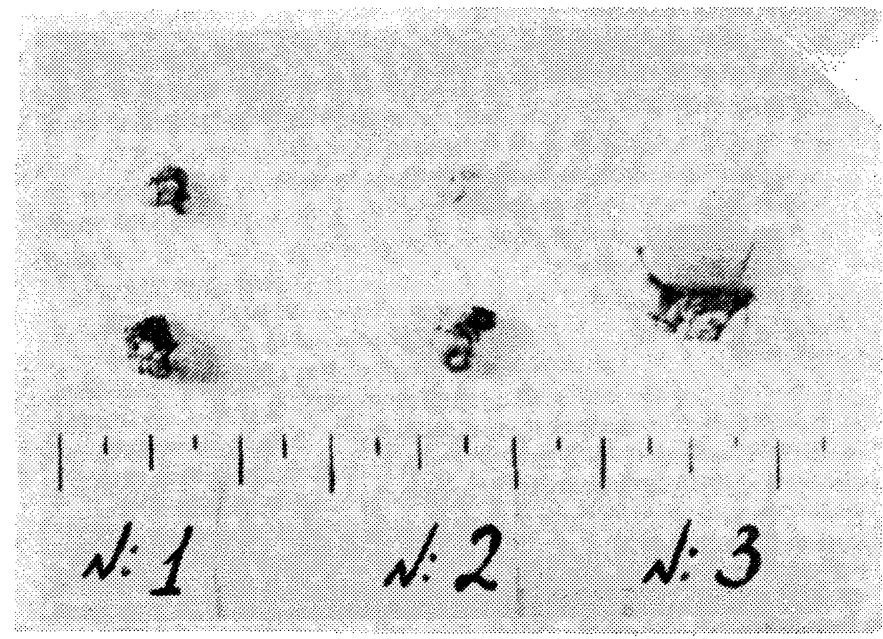

Fig. 5. Dystrophic changes of the ovaries of Japanese quail of the flight experiment and control groups: No. 1: flight experiment, No. 2: synchronous control, No. 3: laboratory control 
Another goal was to study the feeding and mating behaviour and obtain data on structural and physiological changes in adult quail in microgravity.

The quail survived the space trip apparently without any serious problems and one hen has successfully laid an egg. The quail fixed to the feeding tube were able to consume food in a usual way. The non-harnessed quail lost orientation in space. However, in comparison with the newly hatched chicks, their orientation was better and their motor activity less chaotic. One of the non-harnessed birds was even able to reach the feeder and consume some food. As to mating behaviour an absolute apathy was observed in both sexes, perhaps caused by dystrophic changes in ovaries and testes.

Upon return to Earth the quail manifested an altered stature. The head hung toward the chest and the trunk leant forward (Fig. 4). When moving, they could hardly maintain equilibrium, they fell forward or deviated to the sides. Nonetheless, their reaction to food was fairly normal. During the 7-day experiment all the quail had lost some body mass (Sabo et al. 1991).

Table 1 gives the values of blood $\mathrm{Ca}$, estradiol, testosterone, triiodthyronine and corticosterone.

Certain changes were seen in $\mathrm{Ca}$ and $\mathrm{T}_{3}$ levels with a decreasing tendency in the flight experiment and synchronous control. Changes in reproductive functions were manifested by the arrest of egg production, dystrophy of ovaries and testes (Fig. 5) and a decrease in testosterone level (Table 1).

Histologically, a degeneration and depletion of spermatocytes and round spermatids were found. Electronmicroscopically, degenerative changes in gonadocyte nuclei and cytoplasm were observed. Striated muscles (m. gastrocnemius) were characterized by a decrease in density of myofibrils, their space occupied instead by mitochondria with disintegrated inner membranes. Myocyte necrosis was also noted.

Histochemical studies of alcaline and acid phosphatases revealed no changes in flight experiment quail as against controls. In the flight experiment and synchronous controls an increased activity of non-specific esterase was found, confirming the disintegration of muscle tissue.

These functional and morphological changes may be considered as reversible. They were observed both in the flight experiment and synchronous control indicating an involvement of the transport stress (Kočišová et al. 1991).

Table 1

Ca and hormone levels in Japanese quail in the experiment Incubator 2

\begin{tabular}{|c|c|c|c|c|c|c|c|}
\hline & & & 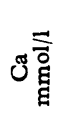 & 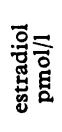 & 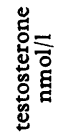 & $*^{*} \frac{\vec{E}}{00}$ & 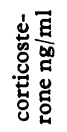 \\
\hline Flight experiment & $\begin{array}{r}9.8 . \\
10.8 . \\
11.8 .\end{array}$ & $\begin{array}{l}\text { 우 } \\
0 \\
0 \\
0\end{array}$ & $\begin{array}{r}0.74 \\
1.02 \\
1.22\end{array}$ & $\begin{array}{l}181 \\
181\end{array}$ & 0.585 & $\begin{array}{l}0.078 \\
0.095\end{array}$ & $\begin{array}{l}90,50 \\
18,35 \\
57.64\end{array}$ \\
\hline Synchronous control & $\begin{array}{l}14.8 . \\
15.8 . \\
16.8 .\end{array}$ & $\begin{array}{l}q \\
+ \\
0 \\
0 \\
+\end{array}$ & $\begin{array}{l}1.00 \\
1.39 \\
3.30\end{array}$ & $\begin{array}{l}229 \\
155\end{array}$ & 0.835 & $\begin{array}{l}0.527 \\
0.632 \\
1.279\end{array}$ & $\begin{array}{l}42.81 \\
41.38 \\
12.54\end{array}$ \\
\hline Laboratory control & $\begin{array}{l}\text { 13. } 8 . \\
13.8 .\end{array}$ & $\frac{9}{d}$ & 1.13 & 152 & 3.42 & $\begin{array}{l}0.093 \\
1.032\end{array}$ & $\begin{array}{l}70.7 \\
42.46\end{array}$ \\
\hline
\end{tabular}

Note: $* \mathrm{~T}_{3}-$ triiodthyronine 


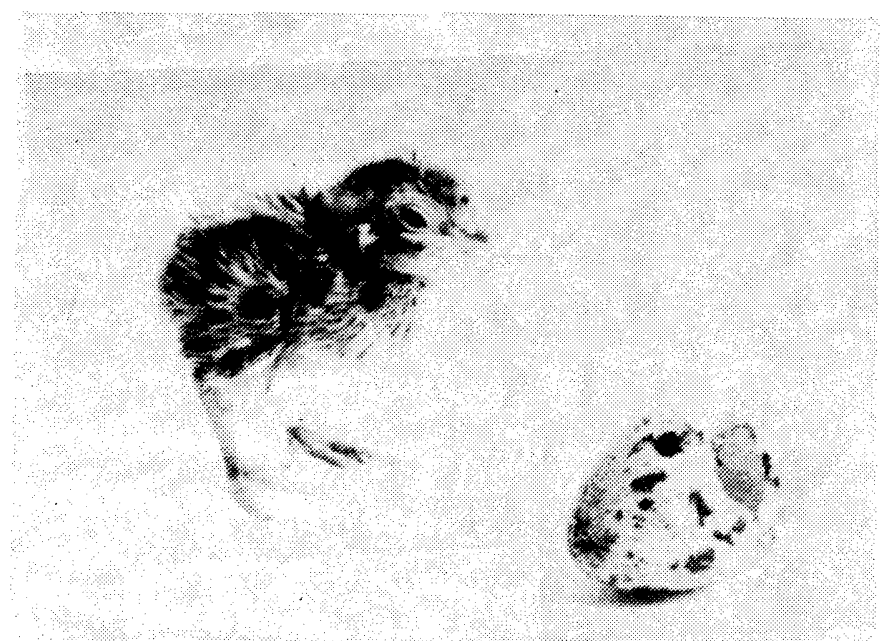

Fig. 6. The male hatched from the egg laid by a quail hen during the orbital station flight

In the crop and caecum content of Japanese quail total counts of lactobacilli, enterococci, streptococci and $E$. coli in two birds of each group were observed.

Significant differences among experimental groups were noted only in $E$. coli counts that were higher in the flight experiment as compared to laboratory control.

The isolated microbes were further identified as follows: 3 staphylococcal strains were classified as Staphylococcus gallinarum sp., 2 strains as Enterococcus gallinarum sp., and 7 strains as $E$. faecium sp. The remaining strains were not typed. The isolates showed low urease and protease activity and no amylase activity.

Most of the strains were resistant to penicillin. The presence of plasmids did not confirm the resistance of isolated strains (Lauková, personal communication).

One quail hen of the flight experiment group was left alive and included in the breeding flock. On day 6 after the return to Earth this hen laid the first egg, proving the reversibility of changes observed in the ovaries of the 2 dissected birds. From subsequently laid eggs, healthy chicks were hatched.

After a 7-day exposure to weightlessness, the egg laid during the orbital flight was returned to Earth and incubated. From this egg a cockerel was hatched and developed to become a healthy individual (Fig. 6) that has parented a number of offspring.

\section{Vplyv mikrogravitácie na embryonálny vývoj a správanie japonských prepelíc}

Bol sledovaný vplyv mikrogravitácie na embryonálny vývoj japonskej prepelice včítane liahnutia, na správanie vyliahnutých kurčiat a na fyziologické funkcie dospelých prepelíc. Bola dokázaná možnosṫ celého embryonálneho vývoja i liahnutia prepelíc $\mathrm{v}$ stave beztiaže. Získali sa prioritné poznatky o senzorno-motoric- 
kom a potravinovom správaní prepelíc vo veku 1-4 dni postembryonálneho života a správaní dospelých prepelíc $\mathrm{v}$ podmienkach mikrogravitácie. Prepelice boli schopné za určitých podmienok prijímat krmivo, no nedokázali sa $\mathrm{v}$ priebehu sledovanej doby pohybove adaptovat $\mathrm{v}$ mikrogravitácii. Ich pohyby boli nekoordinované a chaotické, čo sa prejavilo zvlášt výrazne u kurčiat. U dospelých prepelíc boli po 7-dňovej expozícii v mikrogravitácii získané predbežné výsledky o hladinách hormónov (estradiol, triodthyronin, kortikosteron) a Ca. Zmeny reprodukčných funkcií sa prejavili zastavením znášky, dystrofiou vaječníkov a semenníkov a zniženou hladinou testosteronu. Získali sa prvé výsledky o vplyve mikrogravitácie na mikroflóru TT.

\section{Влияние микрогравитации на эмбриональное развитие и поведение японского перепела}

Проводили исследования микрогравитации на эмбриональное развитие японского перепела, включая вылупление, на поведение вылупившихся цыплят и физиологические функции взрослых перепелов. Была установлена возможность всего эмбрионального развития и вылупления перепелов в невесовом состоянии. Получили приоритетные результаты по сенсорно-двигательному и пищеварительному поведению перепелов в возрасте 1-4 суток постэмбриональной жизни и поведению взрослых перепелов в условиях микрогравитации. Перепелы были в определенных условиях в состоянии принимать пищу, однако в исследуемый период были не в состоянии приспособить движения в микрогравитации. Их движения отличались некоординипрованностью и хаотичностью, что особенно выразительно проявлялось у цыплят. У взрослых перепелов после семисуточного нахождения в микрогравитации получили предварительные результаты уровней гормонов (эстрадиол, трииодтиронин, кортикостерон) и Са. Изменения репродукции нашли проявление в прекращении яйцекладки, дистрофии яичников и семенных желез и в понижении уровня тестостерона. Получили первые результаты по влиянию микрогравитации на микрофпору пищеварительного аппарата.

\section{References}

BOD̆A, K.: Will yielding animals fulfil their function also under cosmic conditions? (in Slovak): Technická práca XXI, 6, 1979, 23-27

BOĎA, K. - BELÁK, M. - MARETTA, M. - KOČIŠOVÁ, J.: Study of Japanese quail embryogenesis under weightlessness (in Russian); In: Cosmic Biology, Gravitational Physiology, SAS, Institute of Animal Physiology Košice, 1984, 263-274

BOĎA, K. - MELEŠKO, G. I. - SABO, V. - SEPELEV, E. Ja.-GURJEVA, T. S. - JURÁNI, M.-KOŠT́́L, L': Embryonic Development of Japanese Quail Under Microgravity Conditions. The Physiologist, $S-34,1991,59-61$

BOĎA, K. - KOŠT̃ÁL, L.-GURJEVA, T. S.-SABO, V.-JURÁNI, M. - DADASHEVA, O. A.: Behaviour of Japanese Quail Under Conditions of Weightlessness (in print)

HULLINGER, R. L. - VELLINGER, M. C. - SHARP, P. E.: Avian Embryogenesis in Microgravity Aboard Shuttle STS-29: Embryonic Survival and Measurement of Developmental Age. ASGSB Bulletin, Vol. 4, No. 1, 1990, 27

JURÁNI, M.-VÝBOH, P. - LAMOSOVÁ, D. -BOĽA, K. - NVOTA, J.: Neurophysiological Response of Japanese Quails to a Short- and Long-term Restraint. In: Scientific Works of the 
Institute of Animal Physiology of the Slovak Academy of Sciences (Ed. K. Boda), Veda, Bratislava, 1980: $231-244$

JURÁNI, M.-VÝBOH, P. - LAMOŠOVÁ, D. - BAROŠKOVÁ, Ž. - SOMOGYIOVÁ, E.BOĎA, K.-GAŽO, M.: The Effect of a 90-day Hypodynamy on the Neurohumoral System, Egg Laying and Metabolism of Proteins in Japanese Quail. The Physiologist 26-S, 1983: $145-148$

JURÁNI, M.-BOĎA, K.-KOŠŤÁL, L.-SOMOGYIOVÁ, E. - LAMOŠOVÁ, D. - VÝBOH, P.-AMBRUŠ, B.-BAUMGARTNER, J.: Selection of Japanese Quail Line Resistant to Hypodynamy. The Physiologist, $S-31,1988$ : 140-142

KOČIŠOVÁ, J. - CIGÁNKOVÁ, V. - MARCANIK, J. - BOĎA, K. - TOMAJKOVÁ, E. DADAŠEVA, O. A. - SABO, V.: Ultrastructural and Histochemical Changes in Tissues of Japanese Quail Exposed to a 7-day Microgravitation. In: Current Trends in Cosmic Biology and Medicine, II. Vol. (Ed. by K. Boda and V. M. Baranov), 1991: 201-209

LAUKOVÁ, A.-KMET, V.-BOḊA, K.: Microflora of Japanese Quail under Space Flight Conditions. In: Current Trends in Cosmic Biology and Medicine, II. Vol. (Ed. by K. Boda and V. M. Baranov), 1991: 225-232.

MÁJEK, Š.-ZONGOR, J.: Incubator-A Device for Experiments in Cosmic Space. Second Micro-Symposium "Svet 90" on Biotechnology and Life Support Systems. Space Research Institute Bulgarian Academy of Sciences, 1991: 68-73

MARETTA, M.-BELÁK, M.-BOĎA, K.-ŠELEPEV, E. Ja.-SIDORENKO, L. A.DADAŠEVA, O. A.-KOČIŠOVÁ, J.: The Development of the Digestive System in Japanese Quail Embryo Under the Condition of Weightlessness. Zborník Čs. Fyziol. spol. Bratislava, 1981

MELEŠKO, G. I. - ŠEPELEV, E. Ja.-GURJEVA, T. S.-BOĎA, K.-SABO, V.: Embryonic Development in Fowls under Weightlessness (in Russian). Space Biology Aerospace Medicine, 25, 1991: $37-39$

PETER, V.-BODA, K.-SABO, V.: Effect of Hypergravitation and Vibration of Hatching Eggs on the Hatchability of Japanese Quails. In: Proceedings and Abstracts, XVI, WORLD's Poultry Congress, Vol. III, Rio de Janeiro, World's Poultry Science Association Brasil Branch, 1978: $286-290$

SABO, V.-BOD̆A, K.-ŠEPELEV, E. Ja.-PETER, V.-NOSKIN, A.: Embryo Development in Japanese Quail Under Weightlessness (in Russian). Scientia Agriculturae bohemoslov. 14, 1982: $141-146$

SABO, V.-BOĎ, K. - GURJEVA, T. S. -DADAŠEVA, O. A.: Changes in the Live - Weight of Japanese Quail and Weight of Their Body Organs After a 7-day Exposition to Microgravity. Acta vet. Brno, 61, 1992: 000-000.

SOUČEK, J.-ZONGOR, J.-POTOCKÝ, I.: Project and Realization of Incubator 1 and Auxiliary Devices to Test the Functioning of the Incubator (in Slovak). In: Kozmická biológia, Gravitačná fyziológia, SAV, Ústav fyziológie hosp. zvierat, Košice, 1984

ŠEPELEV, E. Ja.: Life Supporting Biological Systems. Fundation of Space Biology and Medicine, Vol. III, NASA, Washington, D. C., 1975: 277-313.

ŠUTEK, L. - VARGA, M. - MÂJEK, Š.: Problems and Realization of the Electrical Automation of Regulating and Measuring the Devices of Incubator 1. (in Slovak). In: Cosmic Biology, Gravitational Physiology, SAS, Institute of Animal Physiology, SAS, Košice, 1984: 227-232 